$\begin{array}{lllllllllll} & \text { R } & \text { R } & \text { T } & \text { I } & \text { C } & \text { L } & \text { E } & \text { S }\end{array}$

\title{
Bulgarians and Bulgaria in the Last Quarter of the Nineteenth Century in Jan Grzegorzewski's Publications (Internal Policy, Foreign Policy)
}

Zarys treści: Jan Grzegorzewski, wybitny polski slawista i orientalista, odbył na przełomie XIX i XX w. kilka podroży po Bałkanach. W ich trakcie dokonał wnikliwych obserwacji miejscowych stosunków politycznych, z których wnioski zawarł w kilku opublikowanych na przełomie stuleci książkach i artykułach. Ważne miejsce w jego pracy badawczej zajmowała Bułgaria. Niniejszy artykuł jest prezentacją obrazu tego kraju, postrzeganego przez autora przez pryzmat podjętych w jego pracach wątków - polityki wewnętrznej i zagranicznej.

Outline of content: Jan Grzegorzewski, an outstanding Polish Slavic philologist and Orientalist, undertook several voyages throughout the Balkans at the turn of the $20^{\text {th }}$ century. During those trips he made careful and detailed observations of local political relations, and published his conclusions in several books and articles published at the end of the $19^{\text {th }}$ and early $20^{\text {th }}$ century. Special place in his research work was occupied by Bulgaria. The purpose of the article is to present the image of this country as seen by Grzegorzewski through the prism of the central themes brought up in his writings - internal and foreign policy.

Słowa kluczowe: Jan Grzegorzewski, Bułgaria w XIX w., bułgarska polityka wewnętrzna, bułgarska polityka zagraniczna, wojna serbsko-bułgarska 1885

Keywords: Jan Grzegorzewski, Bulgaria in the $19^{\text {th }}$ century, Bulgarian internal policy, Bulgarian foreign policy, Serbo-Bulgarian War of 1885

The second half of the $19^{\text {th }}$ century, and especially its last twenty five years, was a time of tremendous transformations in Europe. They covered almost all areas of social life, and the part of Europe in which these processes gathered particular pace was the Balkans. The fact of overlapping, in that relatively small space, of political, internal and external, social, ethnic and cultural factors, resulted in calling the Balkan Peninsula, at the beginning of the $19^{\text {th }}$ century, a "barrel of gunpowder", the explosion of which could permanently destabilize the situation in Europe. 
In this respect, the nation that played a very important role was the Bulgarians who, showing great consistency in pursuing their national goals while at the same time predominating in terms of population and, subsequently, also territory over the neighbouring nations, very soon became a key element in regional and pan-European policies. These dynamic processes were observed with great interest not only by politicians and diplomats, but also by wide European social circles, informed by correspondents and columnists of the then newspapers and magazines.

One of them was the outstanding Polish ethnographer, Slavist and Orientalist Jan Grzegorzewski ${ }^{1}$ who, as a war correspondent of Polish and French dailies, had the opportunity to explore the Balkans during his journey to Constantinople in 1877. The great impression that this part of Europe had made on him soon turned into a fascination, which prompted him to travel further to the Balkans in the following years, and finally encouraged him to settle in 1904 in Bulgaria, a country for which he had much affection. As a result of these numerous journeys and more than ten years of residence in Sofia, a number book publications and articles devoted to Bulgarian issues, ${ }^{2}$ based mainly on the results of his own in-depth observations, appeared. At the same time, while working on them, Grzegorzewski also used reminiscences and memoirs, press releases and contemporary studies and monographs. ${ }^{3}$ As a result, his work presenting the Bulgarian political scene, activities on the international scene, and the rivalry of superpowers for areas of influence taking place in this part of the continent had and still have a high cognitive value, although they frequently present his subjective views on particular issues.

Analysing Jan Grzegorzewski's work devoted to the above-mentioned issues, it is not difficult to get the impression that he took a particular interest in issues related to the Bulgarian political system, which he often presented in comparison with the official and behind-the-scenes activities of superpowers, especially of Russia.

\footnotetext{
${ }^{1}$ Jan Grzegorzewski's detailed biography and his academic achievements in: J. Rubacha, "Bułgarzy i Bułgaria w ostatniej ćwierci wieku XIX w publikacjach Jana Grzegorzewskiego (kultura, ludność, gospodarka)", Studia z Dziejów Rosji i Europy Południowo-Wschodniej, 51 (2016), no. 1, pp. $24-27,47$.

2 J. Grzegorzewski, Rok przewrotów (Bułgarya 1885/86), Lwów, 1900; id., "Dragan Cankow”, Świat Słowiański, 7 (1911), vol. 1, no. 77; id., "Stronnictwa bułgarskie za Aleksandra Battenberga", Świat Słowiański, 7 (1911), vol. 2, no. 81; id., "Siedmiomiesięczna walka o samoistność Bułgaryi”, Świat Słowiański, 8 (1912), vol. 1, no. 87; ibid., vol. 1, no. 88; ibid., vol. 1, no. 89; id., "Stronnictwa bułgarskie po przewrotach", Świat Słowiański, 9 (1912), vol. 2, no. 95; ibid., vol. 2, no. 96.

3 These were, among others: A.G. Drandar, La Bulgarie sous le prince Ferdinand, 1887-1908, Bruxelles, 1909; id., Les événements politiques en Bulgarie, depuis 1876 jusqu'à nos jours, Bruxelles and Paris, 1896; Ю. Карцов, Семь лет на Ближнем Востоке 1879-1886. Воспоминания политические и личные, Санкт-Петербург, 1906; С. Радев, Строителите на съвременна България, vols. 1-2, София, 1911.
} 
Taking control of the Bulgarian lands by the Turks at the end of the $14^{\text {th }}$ century was followed by deep and multifaceted consequences. In the context of Bulgaria, the aggression of ethnically and racially alien invaders not only interrupted the development of a rapidly developing state organism, and brought about serious damage, but, above all, significantly influenced the social structure of the population, eliminating local national elites. ${ }^{4}$ At the same time, the Bulgarians, who belonged to the lower social groups because they did not adhere to the Muslim faith, were deprived of all public rights and were relegated to the rank of the so-called rayah, or cheap labour force. ${ }^{5}$ However, over the course of time, and especially since the 1830s, in connection with Turkey's entry into the reform period called the Tanzimat, ${ }^{6}$ the property status of parts of Bulgarian society began to slowly change, leading to the crystallization of a group of rich peasants called Chorbaji, whose general situation did not change substantially until 1878 . However, an increase in prosperity opened up opportunities for an ever increasing number of Bulgarians to be educated outside of Turkey and, at the same time, through them, to transfer the patterns and ideas observed abroad. ${ }^{7}$ As a result, the sense of national identity grew in Bulgarian society and the resistance to the occupying forces intensified, while the Bulgarians began to attempt to throw off foreign domination more actively. It is worth emphasizing, however, that this process was relatively slow until 1878 and, at the threshold of independence, Bulgaria had only a handful of people prepared to work in public service both on the local and the national levels. ${ }^{8}$

This situation became a serious problem after gaining independence. According to the agreements made at the Congress of Berlin, the head of the Russian interim administration in charge of Bulgarian territories after the war with Turkey, Alexander Dondukov-Korsakov, decided to convene the Legislative Assembly in Veliko Tarnovo, the purpose of which was to discuss and adopt the first Bulgarian constitution. This assembly, as Grzegorzewski wrote, "mostly composed of peasants and, in general, people who rarely completed even early school

${ }^{4}$ Grzegorzewski, Rok przewrotów, p. 34.

5 Ibid., p. 35.

6 T. Wituch, Tureckie przemiany. Dzieje Turcji 1878-1923, Warszawa, 1980, pp. 11-19.

7 K. Murzyński, “Serbia i jej przodownictwo”, Niwa, 9 (1880), no. 124, p. 245; J. Grzegorzewski, Stronnictwa bułgarskie po przewrotach, no. 96, p. 773. This process was described by Grzegorzewski, who wrote: "There were no more traces of former boyarship here, still preserved in Bosnia and Herzegovina as Muslim beys; established over the centuries by the power of the Turks, various categories of the privileged rayah, endowed with the so-called bashtina (patrimony) to render professional services to the Ottoman state, and eventually dissolved in the reformist Tanzimates at the beginning of the $19^{\text {th }}$ century, drowned again in the uniform mass of the rest of the rayah, irritated by these Tanzimates on the one hand, the foundation of the independent Exarchate on the other, as well as by external propaganda and revolutionary committees", id., Stronnictwa bułgarskie za Aleksandra Battenberga, p. 81 .

8 Ibid., p. 82. 
education", ${ }^{9}$ approached individual issues very emotionally, which meant that the discussions under way were very fierce. Although this hindered the achievement of consensus, it also educated a new political class which, already during the debate, clustered around the leaders of two antagonistic trends, i.e. liberal and conservative. ${ }^{10}$ Petko Karavelov was the leader of the former, commonly called "the young", his most active co-workers being Dragan Tsankov and Petko Slaveykov. This group, referring to the views of Western European and Russian democratic and revolutionary circles, represented the interests of poorer social classes, and above all the relatively well-off peasantry, craftsmen and minor manufactures, and, as Grzegorzewski recalled: "they perceived themselves as the real sons of the nation starved by five-century-long slavery". ${ }^{11}$ By contrast, the other political camp, commonly called "the old", under the leadership of Todor Ikomonov, supported by Dimitar Grekov, Konstantin Stoilov and Grigor Natchovitch, acted on behalf of the rich peasantry, Bulgarian merchants and industrialists. ${ }^{12}$ Both of these trends soon turned into the first two political parties in Bulgaria. ${ }^{13}$

The protracted disputes over the constitution were passively observed both by the representatives of the Russian interim administration and by the government in St. Petersburg. According to Grzegorzewski, such an attitude was a result of the fact that while some of Russia's political circles questioned, and even contested the liberal provisions that were included in the draft of the Bulgarian Constitution, the tsarist government did not attach much importance to them "since the inevitable, as a consequence of this constitution, chronic conflict between the sovereign and the government, or between each of these state factors and the population, afforded the Russian government sufficient opportunity to intervene and hope to consolidate its influence in Bulgaria in this way". ${ }^{14}$ Hence, the Russians were more active only in terms of the election of the monarch, trying to cluster the feuding parties around the candidate indicated in St. Petersburg, i.e. Alexander

9 Ibid.

${ }^{10}$ Grzegorzewski, Rok przewrotów, p. 34.

11 Grzegorzewski, Stronnictwa bułgarskie za Aleksandra Battenberga, pp. 82-83; Програми, програмни документи и устави на буржоазните партии в България 1879-1918, еd. В. Николова, Д. Саздов, София, 1992, р. 17.

12 Grzegorzewski, Stronnictwa bułgarskie za Aleksandra Battenberga, p. 82; Програми, програмни документи, р. 44.

13 Referring to the disputes conducted by the representatives of both of these trends during the meetings of the Constituent Assembly, Grzegorzewski points out yet another circle clustered around Marko Balabanov and supported by the higher clergy headed by the former Bulgarian Exarch Antim I, commonly called "the centre", which tried to reconcile the feuding parties. However, these actions were not successful and, at the end of the session, the group disintegrated without forming a new party. Balabanov later entered the Conservative Party, formed by the conservatives, Grzegorzewski, Stronnictwa bułgarskie za Aleksandra Battenberga, p. 83.

14 Ibid., p. 84. 
Battenberg, ${ }^{15}$ and since he was not controversial, he was appointed to the Bulgarian throne. ${ }^{16}$

Ascending the Bulgarian throne and assuming power, Alexander faced serious challenges that were a result of the difficult socio-economic situation of the state. From the point of view of the Bulgarian raison d'état, the most important matter was to take care, as quickly as possible, of the issue of taking over the estates abandoned by the Turks, providing peasants with land, and eliminating more and more frequent cases of speculation in agriculture, which posed danger of the outbreak of serious social unrest. Meanwhile, conflicts between the conservatives and the liberals intensified, limiting the possibility of taking decisive steps in respect of these pressing issues and, as a result of the resistance of "the young", ${ }^{17}$ the attempts to establish a coalition government ended in a fiasco. Hence, Alexander decided to entrust the mission of forming the first Bulgarian government to the conservatives and, ${ }^{18}$ at the same time, called a general election. However, contrary to expectations, the election resulted in the liberals' sweeping victory, which was primarily caused by the passive attitude of "the old" during the election campaign. ${ }^{19}$ This did not, however, end internal disputes, which prompted the Russian-controlled prince to dissolve the National Assembly and form a new government headed by Bishop Kliment. Although it was a coalition government, the conservatives played a major role in it, which not only failed to silence the disputes, but also exacerbated the rivalry between the two groups. In this situation, Alexander Battenberg, at the end of 1879, once again dissolved the parliament, hoping that the next election would allow the conservatives to gain the majority, which would provide steady support for the government. However, the election held at the turn of January and February of the following year ended with another spectacular success of the liberals. At the same time, the internal situation in Bulgaria deteriorated further as a result of numerous peasant revolts and serious mistakes made by Kliment's government.

15 Efforts in this field, however, were unnecessary, because, as Grzegorzewski wrote: "the Bulgarian masses, along with the whole of the intelligentsia, were so blindly devoted to Russia, that if they had been ordered to elect a stick to wear the crown, they would have elected it without protest", ibid.

16 Ibid., s. 84, 91; C.J. Jireček, Geschichte der Bulgaren, Prag, 1876, p. 323; A. Pług [A. Pietkiewicz], “Sprawa Bułgarska”, Kłosy, 41 (1885), no. 1059, pp. 246-247; Д. Маринов, Стебан Стамболов и новейшата ни история, vol. 1, София, 1992, pp. 81-100.

17 Grzegorzewski, Stronnictwa bułgarskie za Aleksandra Battenberga, p. 86.

18 Todor Burmov became the prime minister of that government, ibid.; Вънината политика на България. Документи и материали, еd. Д. Косев, vol. 1, София, 1978, p. 17; Jireček, Geschichte, pp. 322, 325; Н. Станев, История на нова България 1878-1928, София, 1929, p. 18; А. Цураков, Правителствата на България, part 1, София, 1996, pp. 7-11.

19 As Grzegorzewski wrote: "Sluggish conservatives either let the election take its own course, or undertook nothing against the maddening propaganda of their opponents in the press, at people's gatherings, in ad hoc associations, or as a result of personal endeavours of electoral agents backed by government officials", id., Stronnictwa bułgarskie za Aleksandra Battenberga, p. 88. 
Bulgarian political disputes, as well as results of elections, were closely followed in St. Petersburg. This situation was primarily due to the fact that Bulgarian parties, which had rivalled so far mainly in internal affairs, began to formulate their views on foreign policy issues at that time. Supported by Battenberg and representing the richer groups of society, the conservatives more and more often opted for the strengthening of relations with the western powers, which, in their opinion, would create chances for a faster development of Bulgarian economy than cooperation with economically weak Russia. The real possibility of losing control over Bulgaria prompted the tsarist authorities to pay more attention to "the young", who, despite often toying with revolutionary slogans, simultaneously manifested their positive attitude towards Russia. Hence, as a result of the efforts of Russian diplomats, Alexander was forced to appoint another government, this time liberal, led by Tsankov.

The thirteen-month rule of the two successive governments of "the young" was judged negatively by Jan Grzegorzewski. Special criticism was directed at both Prime Ministers - Tsankov and Karavelov, accusing them not only of lack of experience or political sense, ${ }^{20}$ but also of lack of refinement, or even elementary manners. About the latter Grzegorzewski wrote:

Karavelov, with whom Davidov, a former Russian agent, was hesitant to shake hands under the pretence of his not washing them, appeared without ceremony at the prince's office in a dishabille jacket, with messy hair on his head and beard, and, gesturing vehemently with his hands, or, in sudden movements, throwing himself back and forth, he provoked so passionate discussions in defence of his papers and plans that the prince fled to further apartments and left him alone. ${ }^{21}$

Grzegorzewski was also critical of the clearly pro-Russian course represented by the liberals, claiming it to be detrimental to Bulgaria, and of their efforts to limit the monarch's powers. It is worth remembering, however, that apart from the changes in the fiscal system indicated and appreciated by Grzegorzewski, "the young" also carried out major reforms in the administrative and agrarian sectors, which significantly contributed to the stabilization of the situation in the country. There were also increasing misunderstandings on the government-monarch line, which motivated Alexander to take action to remove the liberals from power.

The final clash took place in 1881. Taking advantage of the ascension to the Russian throne by Tsar Alexander III, after obtaining his approval, Battenberg suspended the constitution and dismissed the government of the liberals, and the mission to form a new government was taken over by Gen. Johan Casimir Ehrnrooth, who had arrived from St. Petersburg. At the same time, an election

${ }^{20}$ Grzegorzewski, Stronnictwa bułgarskie za Aleksandra Battenberga, pp. 93-94.

21 Ibid., p. 91. 
to the Grand National Assembly was held, which was supposed to sanction the existing state of affairs and to approve Battenberg's proposal of changes. ${ }^{22}$ Owing to the introduction of the state of emergency in the country and the preventive measures taken, the conservatives won a majority of seats in the parliament and, without a discussion, granted the prince powers, "among a huge ovation of the local people and those from the provinces". ${ }^{23}$ The Assembly was dissolved afterwards and Ehrnrooth's government resigned, soon replaced by the State Council playing the role of the government and parliament. ${ }^{24}$ At the same time, efforts were made to remove the liberals from the Bulgarian political scene, eliminating from the press market the newspapers and magazines supporting them, and arresting or forcing some of their leaders and activists to emigrate. ${ }^{25}$

Although this brought about an improvement in the domestic situation, violent action against the pro-Russian-oriented "young" began to raise concerns in St. Petersburg. The negative judgement about Alexander Battenberg was also influenced by the open conflict between him and the Russian ambassador in Sofia, Mikhail Khitrovo, which broke out in the wake of the dispute over the granting of the concession for the construction of new rail connections in Bulgaria. ${ }^{26}$ Therefore, regularly informed about the atmosphere in Russia, Battenberg turned to Tsar Alexander III asking him to delegate two people to assume government positions, and so the new government included Gen. Leonid Sobolev as the Prime Minister and Gen. Alexander Kaulbars as the Minister of War. Contrary to hope, however, this move did not strengthen the prince's position, and the reason for this was primarily the behind-the-scenes activity of the Prime Minister, who sent to St. Petersburg reports "presenting the conservatives as a bunch of swindlers, and the prince as a servant of Austria, pulling Bulgaria from Russian hands, and

22 The plan was to suspend the constitution for seven years. At that time, the full legislative and executive power was supposed to be in the hands of Alexander. The prince also obtained extraordinary powers, which provided him with the opportunity to introduce amendments to the constitution, ibid., p. 95.

${ }^{23}$ Ibid., p. 100.

24 As Grzegorzewski wrote: "As part of its scope of action, the Council was to adjudicate on complaints filed against higher administrative authorities, submit opinions on the breach of the constitution to the Prince, reply to the queries from the ministries, grant extraordinary credits, prepare bills of law, etc.", ibid.

25 Grzegorzewski, Dragan Cankow, p. 358; id., Stronnictwa bułgarskie za Aleksandra Battenberga, p. 102.

26 Grzegorzewski, Stronnictwa bułgarskie za Aleksandra Battenberga, pp. 87, 90, 101. Also on this topic: Jireček, Geschichte, p. 329; Станев, История, pp. 32-33; Цураков, Правителствата, p. 21; Е. Стателова, Дипломация на Княжество България 1879-1886, София, 1979, pp. 81-90. A conflict in this regard began in 1880 in connection with the efforts to obtain a concession for the construction of the Ruse-Sofia line, made by the Russian industrialist Alexander Ginburg. However, supported by Russian diplomacy and the liberals, the idea met with the opposition of Battenberg and the conservatives, who opted for granting the concession to Western European companies. 
subjecting it to Germany". ${ }^{27}$ The dispute growing within the government quickly turned into a government crisis. In early March 1883, "the old" left the government, which forced Battenberg to initiate talks about agreement between the conservatives supporting him and the liberals. In the summer of that year, they ended in success, ${ }^{28}$ which not only allowed to call an election to the National Assembly, in which the conservatives held majority, but also triggered the collapse of the liberal camp. ${ }^{29}$ At the inaugural parliamentary session on the 6 September, Battenberg presented a manifesto in which he announced the restoration of the constitution and issued a decree on the establishment of the new coalition government headed by the liberal Dragan Tsankov as the prime minister, and the conservative Grigor Natchovitch as the finance minister. ${ }^{30}$ In this situation, the Russian generals left Bulgaria, "leaving the prince with a threatening message: 'Nous nous retirons, mais souvenez vous que pour vous même cette affaire sera funeste". ${ }^{31}$

The agreement concluded between the conservatives and the liberals, however, did not last long. Disputes arose both at government meetings and in the National Assembly, and finally the controversy that ensued with regard to the appointment of the upper chamber of the parliament and the introduction of amendments to the electoral law at the end of 1883 led to the fall of the government. Its place was taken over by the new liberal government led by Tsankov. This, however, did not calm the situation because a fraction of the liberals remaining in opposition, clustered around Petko Karavelov, disappointed in the hopes of gaining government positions, launched a violent attack. In numerous publications, they accused Tsankov of "the betrayal of liberalism and almost betraying the country's interests due to the signing of the convention for the construction of the Sofia-Belgrade railway (for Tsaribrod-Niš, and not for Macedonian Skopje)", ${ }^{32}$ and also accused him of being too conciliatory in the border dispute with Serbia, and of the misappropriation of funds at the purchase of the Ruse-Varna railway line by the state. Such a state of affairs caused another political crisis, which resulted, on the one hand, in the resignation of the government and the dissolution of the parliament, and on the other, in the final break-up of the liberal camp into two antagonistically oriented parties. ${ }^{33}$

${ }^{27}$ Grzegorzewski, Stronnictwa bułgarskie za Aleksandra Battenberga, p. 104.

${ }^{28}$ Ibid., p. 108.

${ }^{29}$ Only the moderate wing of the liberals, clustered around Tsankov, decided to participate in the talks with the conservatives. The others, under the leadership of Karalevov, who remained in exile in Eastern Rumelia, still remained in opposition.

${ }^{30}$ Grzegorzewski, Stronnictwa bułgarskie za Aleksandra Battenberga, p. 112.

31 "We are leaving, but remember that it will have a terrible effect on all of you" (Fr.), ibid., p. 108.

32 Ibid., p. 113. The decision in this regard was taken still by the coalition government of the liberals and conservatives, and special criticism was expressed in respect of the granting of the concession for construction to an Austro-Hungarian company.

${ }^{33}$ In connection with the fact that they both referred to liberal traditions, for the purpose of making a distinction Tsankov's supporters began to be called “Tsankovists", and Karavelov's group - "Karavelists". It is also worth pointing out that, according to Grzegorzewski, the main reason 
At the same time, the group led by Karavelov won the election to the next National Assembly held in May 1884, with him assuming power as the prime minister, while Tsankov with his group found themselves in opposition. As a result, the situation in the country continued to be strained, prompting various organizations to take action towards a rapprochement between the two parties. As Grzegorzewski wrote: "In the meantime, their reconciliation and amicable action on the Bulgarian land were much desired by Prince Alexander, as well as by Russia's new diplomatic agent Koyander, although with mutually opposed purposes and directions". ${ }^{34}$

The efforts of Russian diplomacy were primarily dictated by the plans to remove Alexander from the Bulgarian throne, developed for some time in St. Petersburg. Due to the awareness of the fact that Russia's direct interference could be countered by the reaction of other European powers, it was decided to support the part of the Bulgarian political scene that had contested his rule in Bulgaria. In the present situation, however, it was necessary to make the two liberal groups co-operate. As Grzegorzewski writes referring to Simeon Radev's work, ${ }^{35}$ Koyander started acting in this matter shortly after his arrival in Sofia in the spring of 1884, and during the arranged meeting of the two leaders he announced to them that: "The relations with Russia are strained, as you know. Prince Alexander must either be reconciled with the emperor, or leave Bulgaria. Should you think that reconciliation is desirable, I am ready to go immediately to St. Petersburg to this end, if not, then the question of the dethronement must be resolved as soon as possible". ${ }^{36}$ Although both leaders liked the idea of removing Battenberg, Tsankov, for fear of possible consequences, proposed the formation of a coalition government with the conservatives, which would jointly assume responsibility for the monarch's dethronement. However, the idea of co-operation with the conservatives was rejected by Karavelov and, although a co-operation agreement had been signed, no action in this field was taken. ${ }^{37}$ At the same time, Battenberg also attempted to help the leaders of the liberals to reach an agreement. In such an alliance, he a saw a tool of counter-attacking foreign, including Russian, penetration in Bulgaria, ${ }^{38}$ but these

for this split was above all the ambition and rivalry between the leaders, and not any deeper ideological differences. He illustrated this by writing: "The contrary positions exacerbated by the personal relationship between the leaders to such an extent that, as Tsankov said, if he met Karavelov in heaven, he would escape from there to hell", id., Stronnictwa bułgarskie za Aleksandra Battenberga, p. 114; id., Dragan Cankow, p. 358. At the same time, however, the views of the two leaders on the directions of Bulgarian foreign policy were also changing. If Tsankov was clearly demonstrating a pro-Russian attitude, Karavelov began to lean towards the Western Powers.

${ }^{34}$ Grzegorzewski, Stronnictwa bułgarskie za Aleksandra Battenberga, p. 114.

35 Радев, Строителите, vol. 1, p. 458.

${ }^{36}$ Grzegorzewski, Stronnictwa bułgarskie za Aleksandra Battenberga, p. 115.

37 Referring to the information taken from Radev, Grzegorzewski, without denying its truth, doubts that such actions would be feasible, ibid., p. 116.

38 Ibid., p. 117-118. 
efforts also proved unsuccessful. There is no doubt that such a state of affairs was directly influenced by the political circumstances in Europe at that time, which put the Bulgarians in a difficult situation. As Grzegorzewski rightly remarked:

Should we prescind their behaviour towards Russia and the West from all sentiments and historical and cultural factors, and judge it only on the basis of the concrete policy existing at that time, then such people as Karavelov and Tsankov, who being ministers had already come in contact with the great forge of this policy, could not be deluded by the thought that Europe would declare war on Russia in defence of Bulgarian freedom, not to mention its prince. ${ }^{39}$

Realizing this, Bulgarian politicians refrained from taking actions which could negatively affect Bulgaria's international reputation. This attitude was all the more desirable that the issue of the future of the autonomous Turkish province of Eastern Rumelia, established under the Treaty of Berlin, was entering the decisive phase. This province, largely populated by Bulgarian people, remained under direct political and military control of Turkey, but was, according to the will of the superpowers, endowed with a Christian governor, local government, the Provincial Assembly (a substitute for the local parliament), and the provincial police force. ${ }^{40}$

The first general governor of Eastern Rumelia was Aleko Pasha Bogoridi, Bulgarian by descent, who "throwing off the Turkish fez and having put on the national cap, in agreement with the first Russian consul Tseretelev [Alexey Tsereteli], a Georgian, and his secretary Izvolsky, nominated only Bulgarians to the posts of both government directors (the dignity corresponding to the ministers of the northern principality) and prefects of departments" ${ }^{41}$ At the same time, two political trends began to develop in Rumelia, as in the Principality of Bulgaria. They were headed by Ivan Salabashev and Ivan Evstratiev Geshov, although initially they did not show much activity. ${ }^{42}$ The situation changed only in 1881 when, threatened with arrest in the Principality, Karavelov and Slaveykov arrived in Rumelia. ${ }^{43}$ In the magazine Niezavisimost, which they established in Plovdiv, they launched a lively campaign against Alexander Battenberg. At the same time, they joined the ongoing discussion on the possible unification of Eastern Rumelia with the Principality of Bulgaria, supporting the idea of the union. It was on this ground that a rapprochement between them and Salabashev's group, who referred to themselves as liberals, supported by Governor Bogoridi, occurred. However,

39 Ibid., p. 120.

${ }^{40}$ Grzegorzewski, Rok przewrotów, p. 3; H. von Bilimek-Waissolm, Der bulgarisch-serbisch Krieg 1885, Wien, 1886, p. 2; J. Rubacha, A. Malinowski, Historia Bułgarii 1870-1915. Materiały źródłowe z komentarzami, vol. 3: Polityka wewnętrzna, Warszawa, 2009, pp. 43-50.

${ }^{41}$ Grzegorzewski, Stronnictwa bułgarskie za Aleksandra Battenberga, p. 128.

42 Grzegorzewski, Rok przewrotów, pp. 4-5, 113.

43 Ibid., p. 51. 
despite the victory of the liberal party in the election to the Provincial Assembly in 1883, the idea of a rapid unification of Bulgaria did not come to fruition as a result of the changes that had taken place in Rumelia.

A year later, Gavril Pasha Krestovitch, who had dissolved the Assembly and called a new election, was elected governor general, enabling the conservatives gathered around Geshov to take power. ${ }^{44}$ Under the pressure of Russian diplomacy, this group took the stand that the unification should take place in the form of an evolutionary process, and advocated postponing it until a more favourable moment. ${ }^{45}$ With no impact on the course of events, the liberals decided to start acting behind the scenes. On their initiative, the Bulgarian Secret Central Revolutionary Committee (BSCRC) headed by Zachariy Stoyanov was founded in Plovdiv, ${ }^{46}$ which launched a lively propaganda campaign among the inhabitants of the province, which proved very popular. ${ }^{47}$ The Committee also established contacts with Alexander Battenberg and, during the talks in mid-August 1885, a date to start action was scheduled for the end of the following month. ${ }^{48}$ In the meantime, the situation in Rumelia exacerbated, and riots occurred in many places. The local police, whose commanders participated in conspiracy activities, most often did not react. This situation prompted the authorities in mid-September to take a decision to arrest several officers and Stoyanov. ${ }^{49}$ The news thrust the BSCRC to action. As Grzegorzewski wrote, in the morning of September 18th:

Five hundred armed peasants with Tchardafon Veliki [Prodan Prodanov] and his fiancée Nadelka, with unfurled flags and cheering the unification get together in the streets of Plovdiv with Nikolayev's militia, who leads them to the ruler's palace. Following Captain Filov's exciting speech, the hurrays and sounds of church bells, Stoyanov declares the end of the Turkish rule. Escorted out by Nadelka's farcical guard, seated with a broadsword in hand next to him in a carriage, Krestovitch is then taken to the border and set free.

44 Ibid., p. 6.

45 Grzegorzewski, Stronnictwa bułgarskie za Aleksandra Battenberga, p. 131.

46 Grzegorzewski, Rok przewrotów, p. 8. In characterizing him, Grzegorzewski spared no critical words, nor did he hide his admiration: "In the host of those new ringleaders of the idea, Zachariy Stoyanov takes the lead, one of those pathetic talents who, like a meteor, suddenly fall to the ground on a dark night, illuminate the horizon for people and disappear, leaving behind them, for those people, burnt cinders of aerolite instead of the star they have seen so far. By profession, in order, a herdsman and a tailor's kalfa (apprentice), he becomes a journalist, investigator, organizer of the plot and the coup, and finally, after the union, a member of parliament and a parliamentary speaker, without any patronage”, id., Stronnictwa bułgarskie za Aleksandra Battenberga, pp. 131, 137; Also on this subject: id., Rok przewrotów, pp. 7-8.

47 Grzegorzewski, Stronnictwa bułgarskie za Aleksandra Battenberga, pp. 137-138.

48 Grzegorzewski, Rok przewrotów, pp. 11-14; id., Stronnictwa bułgarskie za Aleksandra Battenberga, p. 131.

49 Grzegorzewski, Stronnictwa bułgarskie za Aleksandra Battenberga, p. 138; id., Rok przewrotów, pp. 14-16; R. von Mach, Elf Jahre Balkan. Erinnerungen eines preussischen Offiziers aus den Jahren 1876-1887, [Breslau], 1889, p. 245. 
The same happens to General Drygalski, the commander of the armed forces of the former autonomous province of Turkey, henceforth united with the principality. The unification is a fact. ${ }^{50}$

The power in the province was taken over by the Interim Committee headed by Gieorgi Stranski, ${ }^{51}$ who immediately turned to the Principality of Bulgaria for help, ${ }^{52}$ and to the Russian Tsar with a request to take the union under his protection. At that time, informed about the events taking place in Eastern Rumelia, Alexander Battenberg announced the general mobilization of Bulgarian armed forces and set off for Plovdiv. ${ }^{53}$ On 20 September, in Veliko Tarnovo, he declared a manifesto in which he proclaimed the unification and declared himself prince of North and South Bulgaria, ${ }^{54}$ and, on the next day, arrived in the Rumelian capital.

There is no doubt that the proclamation of unification was joyously received among the Bulgarians but, at the same time, it met with a negative reception in Europe. ${ }^{55}$ Other Balkan states, especially Turkey, ${ }^{56}$ Serbia and Greece, which saw it as a threat to their own interests, protested against the Bulgarian union particularly strongly. ${ }^{57}$ Russia, which did not wish for any changes in the status quo in the Balkans, was also critical of it, and supported Serbia and Austria-Hungary. The unanimous negative assessment of the unification of the Principality of Bulgaria and Eastern Rumelia made by the two powers competing in the Balkan Peninsula induced the Serbian king Milán to undertake military action against Bulgaria on 14 November 1885.

The conflict with Serbia put Bulgaria in a very difficult position. In response to the Bulgarian union, Turkey concentrated its army on the Rumelian border, and although it did not decide to intervene, the threat from the southern neighbour was serious, forcing the Bulgarians to keep a considerable part of their forces in Rumelia, far from the northern theatre of war. The great powers, despite their efforts to strengthen their influence in the Principality of Bulgaria, did not intend to intervene

${ }^{50}$ Grzegorzewski, Stronnictwa bułgarskie za Aleksandra Battenberga, pp. 138-139. Elsewhere (Rok przewrotów, p. 17), Grzegorzewski estimated the number of the insurgents at 700 people.

51 Grzegorzewski, Rok przewrotów, pp. 19, 50, 112; Jireček, Geschichte, p. 349; E. Lipnicki, "Sprawa bułgarska”, Biblioteka Warszawska, 1 (1886), p. 183; Е. Стателова, Р. Попов, В. Танкова, История на българската дипломация 1879-1913 г., София, 1994, р. 46.

52 Grzegorzewski, Rok przewrotów, p. 19; Сръбско-бблгарската война 1885. Сборник документи, ed. Е. Харбова, Л. Цветкова, С. Шанов, София, 1985, p. 18; Външната политика, vol. 1, p. 562; Also on this subject: Pług, Sprawa bułgarska, p. 246.

${ }^{53}$ Grzegorzewski, Rok przewrotów, p. 26.

54 The text of the manifesto see: Grzegorzewski, Rok przewrotów, fn. ${ }^{* *}$, p. 21; Rubacha, Malinowski, Historia Bułgarii, pp. 76-77.

55 Grzegorzewski, Rok przewrotów, pp. 20, 25-26; Von Mach, Elf Jahre Balkan, pp. 248-252, 259.

56 Grzegorzewski, Rok przewrotów, pp. 90-94.

57 Ibid., p. 60; Jireček, Geschichte, p. 350. 
in its defence. On the contrary. Austria-Hungary granted war loans to Serbia, and Russia recalled its officers who had been training the young Bulgarian army until then ${ }^{58}$ which could seriously limit its potential. However, as Grzegorzewski noted, the Bulgarians surpassed the Serbs in terms of what he called "national temperament", which he characterized in the following way:

A Bulgarian is cautious and calm, but firm and persistent; he is not easily discouraged by defeat, he may lose ten battles and go into the eleventh with all peace; in this regard, after the Turkish soldier, he presents the finest military material. A Serb, on the contrary, has more daring, zest and enthusiasm but, besides that, he is sensitive; he will go into fire with more bravado, but will not withstand longer resistance, a victory will encourage him to miracles of bravery, but the first major defeat can be the final one for him. In general, Serbia was more likely to win the campaign thanks to its officers, Bulgaria thanks to its soldiers. ${ }^{59}$

These predictions were fully confirmed on the battlefield.

Initially, however, outnumbering their enemy, the Serbian army took over the initiative and not only pushed back the Bulgarian border troops, but also broke off the defence lines at Tran, Tsaribrod and Kula, and the situation of the Bulgarians, both tactically and strategically, became very serious. Waiting for reinforcements from the south, ${ }^{60}$ Alexander Battenberg, who had arrived from Plovdiv, decided to locate the last defence point in the vicinity of Slivnitsa, located about $40 \mathrm{~km}$ from Sofia. Although it was a very risky decision, intense fortification work began on 16 November. As early as on the next day, the main battle of the entire war, which was to last three days, began at these positions. ${ }^{61}$ On 17 November, the Serbian main forces charging in this direction under the command of King Milan attacked the Bulgarian defence lines, but despite their considerably greater number, they failed to break them. In addition, the Bulgarians launched a counter-attack which resulted in their taking control of the Meca Tsrev Heights and forcing the left wing Serbian units to retreat. Despite this, the Serbs attacked again the following day, but this time they were again driven back and suffered heavy losses. ${ }^{62}$ At that moment, the reinforcements from Rumelia arrived at the battlefield, ${ }^{63}$ which allowed the Bulgarian command to launch a counter-attack, as a result of which Serbian troops were defeated at Komshtitsa and the Serbian

58 Grzegorzewski, Rok przewrotów, pp. 38, 84.

59 Ibid., p. 68; Also on this subject: Lipnicki, Sprawa bułgarska, p. 377.

60 The issue of the fast dislocation of units was given priority. Staying in Plovdiv at that time, Grzegorzewski recalled: "Part of them were carried by endless trains, the rest, unable to get on them, trailed along ordinary roads. Within three days, Philipopol presented an image of a moving armed camp, soaking in new columns of infantry, cavalry and artillery, and then throwing them endlessly into the Balkan vastness", Grzegorzewski, Rok przewrotów, p. 67.

${ }^{61}$ A description of the battle according to Antoni Piotrowski's account: ibid., pp. 74-80.

62 Сръбско-българската война, pp. 304-305.

63 Von Mach, Elf Jahre Balkan, pp. 277-282. 
General Staff stationed in Tsaribrod was directly threatened. Terrified King Milan retreated to Pirot. ${ }^{64}$ The Bulgarians succeeded also in other sections of the front. On the next day, they managed to defeat a Serbian division approaching from the side of Tran and launch an attack from Slivnitsa in the direction of Tsaribrod, which was taken on 23 November after a series of hard battles. Three days later, the Bulgarian army crossed the Serbian border and took Pirot. However, the progress of the Bulgarian army was halted as a result of the intervention of the Austro-Hungarian ambassador in Belgrade, Rudolf Count of Khevenhüller, who on 28 November 1885, demanded that the offensive be stopped immediately. ${ }^{65}$ Fearing that his opposition might have serious international consequences, Alexander Battenberg stopped war operations on the same day and agreed to sign a truce. ${ }^{66}$

Meanwhile, the Bulgarian union and the subsequent events exacerbated the rivalry of the great powers in the Balkans, which had a significant impact on the internal situation in Bulgaria and the changes on the political scene. The deepest ones occurred in the liberal camp which had already been split since 1883 . Immediately after the unification, the "Tsankovists" merged with part of the liberals from Eastern Rumelia, and shortly thereafter they also absorbed the pro-Russian activists of the conservative camp headed by Marko Balabanov and Todor Burmov, forming a group with an unambiguously pro-Russian orientation. At that time, the second liberal faction, clustered around Petko Karavelov, joined by Stefan Stambolov and Vasil Radoslavov, began to be inclined towards cooperation with the Western Powers, especially with Austria-Hungary and Great Britain. In addition to them, after the unification with Eastern Rumelia, former conservatives from the Principality headed by Konstantin Stoilov and Grigor Natchovitch, the Rumelian conservative camp of Ivan Evstratiev Geshov, and independent pro-Russian politicians were also active on the Bulgarian political scene.

Such a system of internal relations in Bulgaria was received with great concern in Russia. Therefore, the tsarist government stepped up their behind-the-scenes efforts to mobilize the Bulgarian "Russophiles". They were well received since, for a long time, these circles had been taking the view that Alexander Battenberg was the main obstacle to restoring close relationships with St. Petersburg and, at the same time, they ever more openly favoured removing him from the Bulgarian throne ${ }^{67}$ and were developing an action plan in this regard, which, having consulted it with Russian diplomacy and received their approval, they decided to put into

${ }^{64}$ Lipnicki, Sprawa bułgarska, p. 377.

65 Grzegorzewski, Rok przewrotów, p. 82; Lipnicki, Sprawa bułgarska, p. 378; Von Mach, Elf Jahre Balkan, p. 330.

66 The war ended with the peace treaty signed in Bucharest on 3 March 1886. The text of the document in: J. Rubacha, A. Malinowski, A. Giza, Historia Bułgarii 1870-1915. Materiały źródłowe z komentarzami, vol. 1: Polityka międzynarodowa, Warszawa, 2006, p. 62.

${ }^{67}$ Grzegorzewski, Rok przewrotów, p. 123; Стателова, Дипломация, pp. 206-215; Стателова, Попов, Танкова, История, р. 93. 
practice.$^{68}$ In the night of 20/21 August 1886, taking advantage of the absence of troops faithful to Battenberg in Sofia, ${ }^{69}$ the conspirators surrounded the prince's palace, ${ }^{70}$ arrested Alexander, and demanded the signing of the abdication act. ${ }^{71}$ Despite his initial resistance, the prince signed the document and was then escorted to the border town of Rakhovo upon the Danube, ${ }^{72}$ through which he was to leave Bulgaria. At the same time, the conspirators sent two telegrams to the military authorities in the main towns of Bulgaria, in which they reported on the $\mathrm{fact}^{73}$ and called for swearing allegiance to the new government. ${ }^{74}$ The implementation of the intention to take control of the army, however, met with the resistance of the military and politicians headed by Stambolov, who did not want to pave the way for the "Russophiles" to seize power. ${ }^{75}$ Despite this, the conspirators continued their efforts, counting on Russia's support and the passive attitude of society ${ }^{76}$ and,

${ }^{68}$ As Grzegorzewski wrote, in the published documents from the investigation into the unsuccessful coup, it was found out that: "Major Gruyev testified that at the end of July Tsankov often visited the Russian diplomatic mission (in Sofia), where he was assured that, in case of the Prince's dethronement, Bulgaria was guaranteed no occupation or external interference, to prove which the correspondence with the Russian government was shown to him", id., Rok przewrotów, p. 123; Also on this subject: id., Siedmiomiesięczna walka, no. 88, p. 253; Станев, История, p. 66; A. von Huhn, Aus bulgarischer Sturmzeit, Leipzig, 1886, pp. 12-14.

69 Grzegorzewski, Siedmiomiesięczna walka, no. 87, p. 194; Also on this subject: Станев, История, p. 67; Von Huhn, op. cit., 24; E. Lipnicki, “Zjazd w Gasteinie i wypadki bułgarskie”, Biblioteka Warszawska, 4 (1886), p. 19.

${ }^{70}$ Grzegorzewski, Rok przewrotów, p. 128; Lipnicki, Zjazd w Gasteinie, p. 18; Von Huhn, Aus bulgarischer Sturmzeit, p. 32; N. Forbes, A.J. Toynbee, D. Mitrany, D.G. Hogarth, The Balkans. A History of Bulgaria, Serbia, Greece, Rumania, Turkey, Oxford, 1915, p. 59; Стателова, Попов, Танкова, История, рр. 93-95.

${ }^{71}$ Grzegorzewski, Stronnictwa bułgarskie za Aleksandra Battenberga, p. 141. Also on this subject: id., Rok przewrotów, p. 128; P. Malinowski, "Militaryzm współczesny", Ateneum, 86 (1897), vol. 2, p. 417; Jireček, Geschichte, p. 354.

72 Grzegorzewski, Rok przewrotów, pp. 129-130, 132, 157; Lipnicki, Zjazd w Gasteinie, p. 18; Von Huhn, Aus bulgarischer Sturmzeit, p. 35.

${ }^{73}$ Grzegorzewski, Rok przewrotów, p. 139; id., Siedmiomiesięczna walka, no. 87, p. 192. Also on this subject: id., Rok przewrotów, p. 139; Von Huhn, Aus bulgarischer Sturmzeit, p. 55.

${ }^{74}$ The government was also to include the following: P. Karavelov, S. Stambolov, D. Tsankov, T. Burmov, Todor Ikonomov, Konstantin Velitchkov, Mikhail Madzarov, V. Radoslavov, K. Stoilov, D. Grekov and Konstantin Nikiforov. As Grzegorzewski rightly points out, at the time the message was sent, the government had not yet been appointed, and in fact was never formed. The consultations on its formation began only a few hours later, and in the course of those talks it turned out that Grekov, Stoilov, Karavelov and Nikiforov did not intend to co-form it. At the same time, staying at that time in Plovdiv, Stambolov expressed his hostile attitude to the coup and the idea of including his person in the new government; Grzegorzewski, Siedmiomiesięczna walka, no. 87, pp. 192-193.

75 Маринов, Стеббан Стамболов, vol. 1, pp. 272-336.

76 As Grzegorzewski wrote: "The coup perpetrators and their supporters, as on the first day, counted on presenting their deed as an act of the will of the people, so again after the formation of the new government and the appearance of the first protests, they directed towards the discipline 
on 21 August, they led to the official resignation of Karavelov's government and appointed the new government with Bishop Kliment as the prime minister. ${ }^{77}$ This situation prompted Stambolov's immediate reaction. As chairman of the National Assembly, he made contact with a group of the military who did not acknowledge the changes, headed by Lt Col. Sava Mutkurov, whom he called to come to Sofia with their loyal troops, ${ }^{78}$ and two days later he announced a proclamation saying that the coup had been carried out in violation of law and denied the legality of the government formed by the conspirators. ${ }^{79}$ Owing to this, he managed to bring the situation in the capital under control. ${ }^{80}$ In an attempt to restore the precoup situation, Battenberg's supporters sent him a telegram in which they called him to come back to his country. ${ }^{81}$ In response to these expectations, Alexander decided to return to Bulgaria. Despite the enthusiastic welcome that the society and Radoslavov's new government prepared for him, ${ }^{82}$ he was aware of the fact that his position was weak, mainly because of Russia's negative attitude towards his coming back to power in Bulgaria. Therefore, immediately upon his arrival in Ruse on 28 August, he sent a message to Alexander III in which he informed him about his return to Bulgaria and asked the tsar for his support in fighting the initiators of the coup, but also declared that he was ready to resign the throne, should this be Russia's wish. ${ }^{83}$ The tsar's answer, however, deprived him of

of the army and the passivity of the people, and their acceptance of what was already a fact", id., Siedmiomiesięczna walka, no. 87, p. 193.

77 Grzegorzewski, Rok przewrotów, p. 142; id., Siedmiomiesięczna walka, no. 87, p. 192; id., Dragan Cankow, pp. 358-359; W.R. Wegnerowicz, “Odrodzenie Bułgaryi”, Literatura i Sztuka. Dodatek do Dziennika Poznańskiego, 2 (1913); Von Huhn, Aus bulgarischer Sturmzeit, p. 67. Besides Kliment, the government was formed by: K. Nikiforov, D. Tsanokov, Khristo Stoyanov, V. Radoslavov, K. Velitchkov and T. Burmov.

${ }^{78}$ Grzegorzewski, Rok przewrotów, p. 149; id., Siedmiomiesięczna walka, no. 87, pp. 194-195; Lipnicki, Zjazd w Gasteinie, p. 24.

79 The text of the proclamation in: Grzegorzewski, Siedmiomiesięczna walka, no. 87, p. 200; Lipnicki, Zjazd w Gasteinie, p. 24. Also on this subject: Станев, История, p. 70; Von Huhn, Aus bulgarischer Sturmzeit, p. 91; Цураков, Правителствата, p. 55. As a result of these efforts, several ministers resigned from Kliment's government. Consequently, on 24 August 1886, a new coalition government headed by Karavelov was formed, but fell in only four days; Grzegorzewski, Siedmiomiesięczna walka, no. 87, p. 202; Von Huhn, Aus bulgarischer Sturmzeit, p. 77; С. Грънчаров, “Русофилските политически сили в България (август 1886 - август 1887 г.)”, Известия на Института за история, 26 (1983), р. 127.

${ }^{80}$ Grzegorzewski, Stronnictwa bułgarskie za Aleksandra Battenberga, p. 203; also on this subject: id., Rok przewrotów, pp. 139-152.

${ }^{81}$ Grzegorzewski, Rok przewrotów, pp. 161-162; Von Huhn, Aus bulgarischer Sturmzeit, pp. 94-95.

82 Grzegorzewski, Rok przewrotów, pp. 165-167; id., Siedmiomiesięczna walka, no. 87, p. 206; Jireček, Geschichte, p. 355; Von Huhn, Aus bulgarischer Sturmzeit, p. 158.

${ }^{83}$ Grzegorzewski, Rok przewrotów, p. 168; Von Huhn, Aus bulgarischer Sturmzeit, pp. 131-132. A. Piotrowski, an eyewitness to the events in Bulgaria in 1886, critically assessed the decision to send the report to the tsar. In an article published in Tygodnik Ilustrowany in 1908, he wrote: "This was the gravest mistake made by Prince Alexander"; A. Piotrowski, "From the history of 
the illusion that he would retain the title of the Prince of Bulgaria. ${ }^{84}$ Therefore, on 7 September 1886, after handing over power to the regency council, he voluntarily left Bulgaria for good. ${ }^{85}$

Alexander Battenberg's departure did not remedy the difficult situation in Bulgaria. ${ }^{86}$ Thus, the all-important task faced by the regency council, formed by Stambolov, Karavelov and Mutkurov, ${ }^{87}$ was the problem of the normalization of relations in the country and the election of a new monarch. Activities in these areas were begun with great commitment, which was dictated primarily by disturbing news from St. Petersburg. Although Alexander's abdication was welcomed there, both the press ${ }^{88}$ and the politicians grew unhappy with the retention of power by the anti-Russian political circles in Bulgaria. Yuri Kartsov, the Russian consul in Vienna, expressed it clearly saying: "What is the advantage of the fact that Battenberg is not here [...], since his creatures have remained and all power is in their hands" ${ }^{89}$ Therefore, already in mid-September 1886 , Gen. Nikolai Kaulbars ${ }^{90}$ arrived in Bulgaria with a special mission. According to the guidelines he had received in St. Petersburg, ${ }^{91}$ he took action to strengthen the anti-government opposition..$^{92}$ In pursuit of these tasks, he demanded from the regency council the abolition of the state of emergency and the release of the arrested conspirators against Prince

the Tsardom of Bulgaria. Personal Memoirs", Tygodnik Ilustrowany, 42 (1908), p. 847; Also on this subject: Jireček, Geschichte, p. 355; Lipnicki, Zjazd w Gasteinie, p. 25; Forbes, Toynbee, Mitrany, Hogarth, The Balkans, p. 59; Von Huhn, Aus bulgarischer Sturmzeit, p. 99, 108.

${ }^{84}$ Grzegorzewski, Rok przewrotów, p. 168; id., Siedmiomiesięczna walka, no. 87, p. 205; Von Huhn, Aus bulgarischer Sturmzeit, p. 132. This was also affected by the opinions of other superpowers on this matter. As Grzegorzewski wrote: "The second crucial moment for the prince was Bismarck's dispatch, which illustrated the tsar's dispatch and clearly indicated the necessity of abdication. France, already flirting with Russia at the time, was just like Bismarck on its side. Kalnoky behaved indifferently, turning his eyes to Bismarck. Italy's position was also reserved. Only the English government, partly because of their conviction, partly because of Queen Victoria's wishes, took a strong position firmly demanding that the prince remain on the throne, although, in addition to moral support, not promising any material backing"; Grzegorzewski, Siedmiomiesięczna walka, no. 87, p. 204.

${ }^{85}$ Grzegorzewski, Rok przewrotów, pp. 169, 188-194 ff.; id., Siedmiomiesięczna walka, no. 87, pp. 205-206; Forbes, Toynbee, Mitrany, Hogarth, The Balkans, p. 59; Von Huhn, Aus bulgarischer Sturmzeit, p. 158; Цураков, Правителствата, p. 62.

${ }^{86}$ Grzegorzewski, Siedmiomiesięczna walka, no. 87, p. 206.

87 Ibid.; Wegnerowicz, Odrodzenie Bułgaryi; Грънчаров, Русофилските политически, p. 137.

88 Quoting a Russian newspapers, Grzegorzewski wrote: “The most effortless solution to the present Eastern crisis is the Russian occupation of Bulgaria, to which the general situation is very conducive"; id., Siedmiomiesięczna walka, no. 87, p. 207.

89 Ibid.

90 Grzegorzewski, Rok przewrotów, p. 239; id., Siedmiomiesięczna walka, no. 88, p. 250; Wegnerowicz, Odrodzenie Bułgaryi; Маринов, Стефан Стамболов, vol. 2, pp. 8-16, 20-34; Von Huhn, Aus bulgarischer Sturmzeit, pp. 219-264. Nikolai was the brother of Alexander Kaulbars, the former minister of war in Sobolev's government.

${ }_{91}$ Grzegorzewski, Rok przewrotów, p. 221; id., Siedmiomiesięczna walka, no. 88, pp. 250-251.

92 Вгншната политика, vol. 2, pp. 106-107, 110. 
Alexander, ${ }^{93}$ as well as postponing the election to the Great National Assembly, ${ }^{94}$ which was to elect a new Bulgarian monarch. The Bulgarian authorities responded negatively to these demands and eventually decided to call a general election. ${ }^{95}$

In response, Kaulbars went on a tour around Bulgaria, ${ }^{96}$ during which he intended to conduct active anti-election agitation among the inhabitants of towns and villages, and especially among the officers of provincial garrisons. The effect of these actions, however, was rather modest, although in some places bloody riots took place. The course of the events in Dupnitsa was presented by Grzegorzewski, who wrote:

An antagonized crowd of peasants with the slogan "Netcheme izbory, sakame Rusiya, Rusiya danik nye vzima" (we do not want elections, we want Russia, Russia does not levy taxes) threw themselves at the electoral commission, then at the office from where Dimitrov, the county head, was hauled out, beaten, dragged by the legs on the cobblestones, among the howls "da zhivieye ruskiya tsar" [Long live the Russian Tsar], the dying man was thrown into the river, hurling insults at his dead body. Then, the elated and triumphant riff-raff attacked in one of the schools the parliamentary deputies Zograf and Gryntcharov, or the teacher Papuktchiyski: they were dropped from the first floor headlong onto the pavement and beaten to death with clubs, and Gryntcharov also had his head stabbed with knives and his abdomen ripped open. ${ }^{97}$

However, these incidents met with rapid and decisive actions of law enforcement forces and the army, which restored law and order by force, and arrested the culprits. Thus, despite Kaulbars' efforts, the election was held, but this did not mean the end of Russian agitation in Bulgaria, or locally erupting riots. ${ }^{98}$ At the same time, on 24 October 1886, one week before the inaugural parliamentary session, the Russian diplomatic mission in Sofia handed over to the Bulgarian government a note saying that Russia considered the Assembly to be illegal and, therefore, it would not respect decisions adopted by it. ${ }^{99}$ In the following days, however, information about a military intervention in Bulgaria, planned by St. Petersburg, appeared. ${ }^{100}$ This information deeply troubled the regency council,

93 Ibid., vol. 2, p. 95. The conspirators were finally released at the end of October 1886 at the explicit request of Bismarck, who, in view of Austria-Hungary's strong involvement in the Balkan cause, sought to avoid conflicts with Russia with respect to the Bulgarian issue; Grzegorzewski, Siedmiomiesięczna walka, no. 89, p. 352; Станев, История, pp. 75-76; Also on this subject: Външната политика, vol. 2, pp. 106-107.

${ }^{94}$ Grzegorzewski, Siedmiomiesięczna walka, no. 88, p. 251; Piotrowski, From the history of the Tsardom, p. 847; Грънчаров, Русофилските политически, р. 139.

95 Grzegorzewski, Siedmiomiesięczna walka, no. 88, p. 251.

96 Ibid., pp. 254-258; id., Rok przewrotów, p. 253.

97 Grzegorzewski, Siedmiomiesięczna walka, no. 88, pp. 259-260.

98 Ibid., pp. 352-353.

99 Grzegorzewski, Rok przewrotów, p. 247.

100 Grzegorzewski, Siedmiomiesięczna walka, no. 89, pp. 351-352. 
but did not prevent the election of the Danish prince Valdemar to the Bulgarian throne on 10 November $1886 .{ }^{101}$ Although he refused to accept the crown, it became clear that Kaulbars' actions so far had not yielded any results, nor had they influenced the decisions made by the Bulgarians in any way. Consequently, on 20 November, the Russian diplomat left Sofia and the tsarist government broke off diplomatic relations with Bulgaria. ${ }^{102}$ In this situation, the threat of Russian intervention had increased significantly, and the ongoing agitation by Russian agents destabilized the internal situation. Numerous conspiracies and riots proliferated, the largest of them being the anti-government military uprising in Ruse and Silistra in March 1887. ${ }^{103}$ However, it was quickly suppressed, its commanding officers arrested and sentenced to death. ${ }^{104}$

The unstable situation in the country prompted the regency council to take action to change it as quickly as possible, and the biggest hopes were pinned on the election of a new monarch. That is why, at the end of November 1886, a delegation composed of Konstantin Stoilov, Dimitry Grekov and Konstantin Kalchev was sent to tour Europe in search of a suitable candidate. ${ }^{105}$ As Grzegorzewski wrote:

Not allowed at St. Petersburg, and coldly and privately received in Berlin and Paris, and semi-officially at Kalnoky's, welcomed everywhere by European audiences with curiosity, to Pest, Vienna, Rome and London, in a friendly and even enthusiastic way, the delegation received the greatest support from the Italian Robillant [Carlo Felice Nicolis, conte di Robilant] and the English Iddesley [Stafford Henry Northcote, $1^{\text {st }}$ Earl of Iddesleigh]. ${ }^{106}$

However, the Bulgarians were always advised to maintain self-restraint in their activities and pay attention to the attitudes of Russia. In the meantime, St. Petersburg dismissed the possibility of any discussion about this issue and held that the candidacy of Nicholas, Prince of Mingrelia, proposed by Russia, was final. ${ }^{107}$ In connection with the adamant stance of the Russian government on this issue, the Bulgarian authorities became convinced that the only

101 Ibid., p. 355; Also on this subject: Jireček, Geschichte, p. 356; Маринов, Стеффан Стамболов, vol. 2, pp. 34-56.

102 Grzegorzewski, Rok przewrotów, p. 260; id., Siedmiomiesięczna walka, no. 89, p. 356; Malinowski, Militaryzm współczesny, p. 417; Also on this subject: C. Jankowski, Na gruzach Turcji. Zarysy historyczno-publicystyczne, Warszawa, 1915, p. 176; Цураков, Правителствата, p. 62.

103 Grzegorzewski, Siedmiomiesięczna walka, no. 89, pp. 364-368; Also on this subject: Piotrowski, From the history of the Tsardom, pp. 847-848; Маринов, Стефан Стамболов, vol. 2, pp. 72-86 and 102-124; Грънчаров, Русофилските политически, р. 145.

104 Grzegorzewski, Siedmiomiesięczna walka, no. 89, p. 368.

105 Ibid., p. 357.

106 Ibid.

107 The Bulgarians rejected this candidature, and Stambolov commented on it with a sarcastic remark that "Bulgaria may not elect this prince because the Treaty of Berlin forbids the resettlement of the Cherkess to Bulgaria"; ibid. 
counterbalance to his person could be provided only by a candidate enjoying the support of the Habsburg monarchy. Consequently, it was decided to pay more attention to the person of Prince Ferdinand Sachsen-Coburg und Gotha, whom the Austrians had indicated during the visit of the delegation to Vienna. ${ }^{108}$ As predicted, his candidacy met with firm Russian resistance, and Turkey also expressed its reservations. However, the latter allowed preliminary consultations on the candidate nominated by the Bulgarian side, though it stated that it would be guided by the position of St. Petersburg when making the final decision. In spite of this, talks with the Turkish government were initiated by the Bulgarian envoy to Constantinople Georgi Vilkovich, and Dragan Tsankov sent to the Turkish capital. ${ }^{109}$ However, they did not produce any results and were soon broken off. ${ }^{110}$

In the meantime, the growing domestic crisis forced the regency council to take action immediately. On 7 July 1887, the parliament appointed Ferdinand Coburg to the Bulgarian throne and called him to arrive in Sofia. Certainly, his election met with opposition from Russia. St Petersburg's uncompromising position on this issue not only prevented Ferdinand's acknowledgement by the great powers as the Bulgarian monarch, but also induced Turkey, which held the nominal superiority over the Principality of Bulgaria, to refuse to approve the decision of the National Assembly. Thus, the situation of Ferdinand was extremely complicated, ${ }^{111}$ which hindered his exercise of power and carrying out foreign policy. Stambolov, who headed the government, ${ }^{112}$ exercised the actual power in the country, and Coburg was considering resignation from office. ${ }^{113}$ At the same time, significant changes took place on the Bulgarian political scene. The camp of the "Karavelists" was disintegrated, and politicians representing pro-Western attitudes seceded. ${ }^{114}$ They formed two groups. The first of those, headed by Vasil Radoslavov, adopted the name of the Liberal Club (Либерален клуб) at the end of 1887, and the second, led by Stefan Stambolov, was transformed into the People's Liberal Party (Народнолиберална партия), and for a long time was the political

108 Grzegorzewski, Stronnictwa bułgarskie po przewrotach, no. 95, p. 768.

109 Грънчаров, Русофилските политически, pp. 140-141.

110 Външната политика, vol. 2, pp. 234-237. It is worth noting that, at the same time, the Bulgarian side held consultations on averting the internal crisis and establishing a coalition government representing all political parties; Grzegorzewski, Siedmiomiesięczna walka, no. 89, pp. 358-364.

111 Grzegorzewski, Stronnictwa bułgarskie po przewrotach, no. 95, p. 768; Piotrowski, From the history of the Tsardom, p. 847.

112 The government with Stambolov as the prime minister was formed on 1 September 1887; Grzegorzewski, Stronnictwa bułgarskie po przewrotach, no. 95, p. 763; Jireček, Geschichte, p. 356; It replaced Konstantin Stoilov's government, which was constituted after the election of Ferdinand as Prince of Bulgaria.

113 F. Crispi, Memoiren, Berlin, 1912, p. 277 ff.

114 Jireček, Geschichte, p. 297. 
backbone of the government. ${ }^{115}$ In their political action, Stambolov's group was supported by the conservatives headed by Stoilov (who held similar views) and the Rumelian conservatives led by Geshov. The other side of the political scene was composed of the "Tsankovists" and the remaining "Karavelists", who formed the opposition "Russophile" camp.

The moment when Stambolov took the helm of the government, and especially the policy he pursued, constituted, according to Grzegorzewski, "an epoch-making breakthrough in the life of modern Bulgaria". ${ }^{116} \mathrm{He}$ was particularly appreciative of the actions which, on the one hand, allowed Bulgaria to escape from the Russian supervision and, on the other hand, brought it closer to the Western Powers, ${ }^{117}$ as well as of the efforts made to remove the pro-Russian opposition from political life. At the same time, the researcher pointed to Stambolov's achievements in internal policy, in particular, the changes made in the constitution, the development of Bulgarian armed forces, the reform of education, administrative changes, and the great investment movement that "brought Bulgaria closer to European life than it had ever been before" ${ }^{118}$ Grzegorzewski had a positive attitude to the methods of exercising power, which already at that time became to be called the "regime". As he wrote: "Almost eight years of his rule swept like a hurricane, devastating old dams and sturdy oaks on the way, flooding the road of its march with bloody victims, but a hurricane that cleansed the atmosphere, and a flood that left a fertile layer of silt for the seedlings of the future". ${ }^{119}$

There is no doubt that the large-scale actions of the Stambolovists brought Bulgaria closer to the Western Powers and significantly stabilised the situation in the country, but creating favourable conditions for a deeper penetration by the Western European capital not only ruined the key sectors of the economy, but also increased the country's external debt, and with time the dictatorial methods of rule along with the blocking of the attempts to reach an agreement with Russia awakened the growing dissatisfaction of society. Hence, in the spring of 1894, Ferdinand decided to dismiss Stambolov, ${ }^{120}$ and entrusted Konstantin Stoilov with the mission of forming a new government.

115 Програми, програмни документи, pp. 114-115, 177. In 1895, Radoslavov's group changed its name to the Liberal Party (Либерална партия), and it was colloquially called the "Radoslavists"; Stambolov's party was commonly referred to as the "Stambolovists".

116 Grzegorzewski, Stronnictwa bułgarskie po przewrotach, no. 95, p. 763.

117 It is worth emphasizing that Grzegorzewski in his work repeatedly manifested his anti-Russian attitude, which was undoubtedly derived from the views of the predominant part of the Galician academic world, with whom he maintained close contacts. These views significantly influenced the arguments he formulated, and sometimes led to thoughtless overinterpretation of the facts presented. This is particularly evident in the uncritical assessment of Stambolov's actions, which is debated still today in the Bulgarian academia.

118 Grzegorzewski, Stronnictwa bułgarskie po przewrotach, no. 95, p. 763.

119 Ibid., p. 764.

120 Ibid., p. 768. 
The fall of the "Stambolovian regime" began an almost 15-year-long period of dynamic transformations of the Bulgarian political scene. Its first act of it was the establishment, already in 1894, of the People's Party (Народна партия), commonly known as "Narodnyaks", which was formed as a result of the unification of the conservatives led by Stoilov and the former conservative Rumelian camp headed by Geshov and Ivan Vazov. ${ }^{121}$ In the following years, the programmes of individual political groups were gradually becoming similar, which was a characteristic feature of the changes on the Bulgarian political scene. As Grzegorzewski wrote: "Russophilia and Russophobia, which were in Stambolov's time the ruling principles of the camps, have now rolled up their banners, just as regimental banners are rolled up into sheaths to be kept in a monarch's palace, to be taken out from there in convenient circumstances". ${ }^{122}$ At the same time, the stabilization of the internal situation, and especially the temporarily decreased tension on the international scene, allowed Ferdinand to pursue his policy independent of the slogans and ideology of the Bulgarian parties.

He left military matters and foreign policy to himself alone and entrusted the respective ministerial offices in the government, regardless of which party was in power, to non-party figures, personally trusted and dependent on him. In all other matters, he gave the ruling party free rein, intervening only when their action interfered with his plans, or when he considered the period of the party's power to be sufficient to give way to another one. ${ }^{123}$

Such a state of affairs resulted in the fact that ideological issues influenced further changes only to a limited extent, and more often they were caused by the personal ambitions of individual leaders, or were a result of the crystallization of, and the increase in the political awareness of social or occupational groups which had been disadvantaged in this field.

In 1899, there was a split within the ranks of the "Narodnyaks", from whom the faction under the leadership of Konstantin Velitchkov broke away. It merged with the "Tsankovists" and the group adopted the name Progressive Liberal Party (Прогресивнолибералната партия). In turn, in 1903, a group of activists headed by Todor Vlaykov and Naycho Tsanov, who two years later formed the Radical-Democratic Party (Радикалдемократическа партия), stepped out of the camp of the "Karavelists" who, since 1896, had used the name Democratic Party (Демократическа партия). The "Radoslavists" did not escape splits, either. In 1904, their ranks were left by Dmitri Tonchev's faction, transformed into the Young Liberal Party (Младолиберална партия). There were also opposite processes at that time. At the end of the 1890s, there was a consolidation of the People's Liberal Party, dispersed after Stambolov's death, which was next

\footnotetext{
121 Ibid., p. 766.

122 Ibid., p. 769.

123 Ibid., pp. 769-770.
} 
headed by Dimitri Petkov. Workers and peasants also became more active. In 1894 , as a result of the unification of the two pre-existing organizations, i.e. the Bulgarian Social Democratic Party (Българска соииалдемократическа партия) and the Bulgarian Social Democratic Union (Български социалдемократически съюз), Bulgarian Social Democratic Workers' Party (Българска работническа соииалдемократическа партия) was formed. Already in 1903, however, it split up into two independent and antagonistically oriented groups using the same name. Its left wing, headed by Dimitar Blagoev, established the party BSDWP "Narrow Socialists" (БРСДП - тесни социалисти), commonly referred to as the "Tesnyaks". On the other hand, its right wing, centred around Yanko Sakazov, formed a party that adopted the name BSDWP "Broad Socialists" (БРСДП - чироки соииалисти). In the last days of December 1899, the Bulgarian Agrarian Union (Български земеделски съюз), headed by Yanko Zabunov, was also formed by peasants. Initially, it was a trade union, but in early 1901 it became a political party - the Bulgarian Agrarian People's Union (Български земеделски народен съюз). ${ }^{124}$

By classifying Bulgarian groups through the prism of their political programs, Grzegorzewski developed a schema in which, in his view, "socialists, radicals, and agrarians would have to be counted among the left, extreme for the former, moderate for the latter; progressive-liberals and Narodnyaks would form the right with the extreme hint for the latter; the rest, i.e. the liberals, national-liberals, young-liberals and democrats, would constitute the centre", ${ }^{125}$ but he immediately pointed out that this schema "did not quite correspond to practical reality". ${ }^{126}$ The specificity of the Bulgarian groups lay in the development of possibly wide-ranging programs, which was dictated by the desire to win the largest possible group of voters and create an appropriate basis for agitation and political struggle. It also often resulted from the lack of experience or knowledge of the law. Thus, most declarations were common to the groups, ${ }^{127}$ the promises made were seldom kept in a broader context, the most important issue was the takeover of power, although, in connection with the aforementioned Prince's policy, it was not always a derivative of the program or the presented activity. Such a state of affairs created a specific picture of parliamentary elections. As Grzegorzewski wrote:

So it is not only in Bulgaria, but, reportedly, also elsewhere: every party strives for power and wants to possess it; there are no exceptions in this regard. The only difference is that

124 Ibid., pp. 772-775.

125 Ibid., p. 775.

126 Ibid.

127 Picturing this situation, Grzegorzewski wrote: “Apart from temporary or occasional programmes, all of the four liberal parties do not differ in their social principles, as their older representatives did not differ from their Tsankovist mother. There are sometimes disputes between them as to this or that aspect of those principles, however, they are somewhat scholastic rather than theoretical or practical", ibid., p. 776. 
when in constitutionally strongly developed countries the majority of the parliament that has emerged from the elections becomes the ruling one and wins a majority of seats, in Bulgaria, on the contrary, a party appointed to power, even if it held only a few votes in the parliament before, wins a majority of seats in the election called by them. ${ }^{128}$

As a result, after the election, citizens enjoyed relatively little respect from politicians, and their rights were often violated.

Nowhere in Europe, Grzegorzewski wrote, is a minister so omnipotent a master of the fate of citizens in official positions, as in Bulgaria. [...] There is no appeal against his verdicts, while even in Russia you can appeal to the Senate. This position could be compared with the position of the vizier in old Turkey, with the difference that such a vizier is in Bulgaria the each and every minister of each ministerial office. ${ }^{129}$

But it was not only ministerial positions that were fought for in the elections. Victory guaranteed positions throughout the whole state administration, which was treated as typical "electoral spoils". The so-called "party quadrille"130 included officials from all levels and professions, from street-based policemen to school head teachers and directors of state-owned enterprises, from street cleaners to the president of the court of final appeal. Neither the predisposition, nor the education or personal situation of the dismissed employee was taken into consideration in this staff turnover. This situation was seriously criticized by Grzegorzewski, who saw it as a threat to the state and society. ${ }^{131}$

There is no doubt, however, that the subsequent Bulgarian governments made efforts to make Bulgaria, on the outside, look more similar to other European countries as quickly as possible. No expense or effort was spared to achieve this goal, without paying attention to the fact that a significant part of the former came from loans or credits, most often foreign ones. They were inspired by the new needs and desires that affected Bulgarian society after regaining independence. ${ }^{132}$

128 Ibid., p. 770.

129 Ibid., p. 777.

130 Ibid., no. 96, p. 817.

131 Ibid., p. 818.

132 Ibid., no. 95, p. 782. Significant changes took place in the appearance of major cities, especially in Sofia, where new public buildings, churches, waterworks, etc. were erected. At the same time, some processes hitherto unknown in Bulgaria occurred. Characterizing them, Grzegorzewski wrote: "School boys in bars and cafés exercise their sexual powers on animals and birds or, at the seashore, they publicly organize Sodom and Gomorrah, or gamble playing dice in front of their own school $[\ldots]$ and when passers-by react, they threaten them with fists or drive them away pelting stones, while at the same time, teachers at school refuse to intervene, saying that their task is to teach and not to bring up children in the street; maternity hospitals (maichindom) for poor women in childbed are filled with 14-year-old female junior high school students; and the young university is making its debut not only in applauding these performances, but also in organizing flirtations of male and female listeners with party organizations in the name of constitutional civil liberties and academic autonomy"; ibid., no. 96, p. 815. 
At the same time, many areas were underfunded or deprived of any financial resources at all. ${ }^{133}$

The political history of Bulgaria in the last quarter of the $19^{\text {th }}$ century was extremely complex. The regaining of independence set for the young nation a number of tasks that were to lay the foundations of its statehood and secure its important place in Europe. Political activities, both in the internal and international dimensions, were one of these tasks. This complex process was observed, described, and commented by Jan Grzegorzewski, without whose work it would be difficult to understand its individual elements.

\section{Bulgarians and Bulgaria in the Last Quarter of the 19th Century in Jan Grzegorzewski's Publications (Internal Policy, Foreign Policy) Abstract}

The period of five-century "Turkish yoke" of the Bulgarian lands brought up many deep and multifaceted changes in almost all areas of social life. The Bulgarian population, pushed aside on the margin of social life and deprived of almost all public rights, were unable to reconstruct their elites, destroyed physically and ideologically during the Turkish invasion of the Balkans. And it was for this reason that on the threshold of independence the Bulgarians had only a handful of people prepared to lead the nation and to perform a public service both on a local and national scale. The issue became especially important after Bulgaria regained its statehood in 1878, and social and economic problems of the young state were aggravated by the rivalry of the great powers fighting for influence in this part of Europe, which effectively attracted the attention of developing political milieux. This caused never-ending disputes within the Bulgarian political circles between supporters of a rapprochement with the West and advocates of closer relations with Russia, which, in turn, led not only to numerous political crises, but also implied changes in the highest levels of the government. Only the utmost determination did make it possible for the Bulgarians to overcome internal political problems and to make Bulgaria the leader of other Balkan countries already in the early 19th century. Those complex processes were observed, described and commented upon by Jan Grzegorzewski, and his texts are a perfect source of knowledge both for historians, and other scholars.

\section{Болгары и Болгария в последней четверти XIX в. в публикациях Яна Гжегожевского (внутренняя и внешняя политика) \\ Аннотация}

Период пятисотлетнего турецкого ига болгарских земель вызвало глубокие и многоаспектные перемены почти во всех сферах тамошней общественной жизни. Болгары, столкнутые на обочину и лишенные почти всех публичных прав, были не в состоянии предпринять действия по восстановлению своей элиты, которая была физически или идеологически уничтожена еще во время вторжения турок на Балканы. Из-за чего на

133 Ibid., no. 96, pp. 819-820. 
пороге обретения независимости болгарский народ имел в распоряжении лишь горстку людей, подготовленных к лидерству и несении государственной службы, как в местном, так и в общегосударственном масштабе. Эта проблема приобрела особенное значение после реактивации болгарской государственности в 1878 г., когда на трудности общественного и экономического характера, скопившиеся перед молодым государством, наложилось тогдашнее соперничество держав за сферы влияний в этой части Европы, которое эффективно поглощало внимание только что создававшихся политических сред. Такое положение вещей приводило в Болгарии к бесконечным спорам между сторонниками сближения с Западом и сторонниками укрепления отношений с Россией, что обернулось не только многочисленными политическими кризисами, но и повлекло за собой изменения в высших эшелонах власти. Лишь необычная решительность в стремлении к национальным целям позволила болгарам не только одолеть внутренние политические проблемы, но и уже в начале XX в. сделать свою страну лидером среди других балканских государств. За этими сложными процессами наблюдал, описывал и комментировал Ян Гжегожевский, а его работы являются отличным источником знаний, как для историков, так и для представителей других научных дисциплин.

Перевод Агнешка Поспишил

\section{Bibliography}

\section{Archival material}

Bilimek-Waissolm H. von, Der bulgarisch-serbisch Krieg 1885, Wien, 1886.

Crispi F., Memoiren, Berlin, 1912.

Drandar A.G., La Bulgarie sous le prince Ferdinand, 1887-1908, Bruxelles, 1909.

Drandar A.G., Les événements politiques en Bulgarie, depuis 1876 jusqu’à nos jours, Bruxelles and Paris, 1896.

Forbes N., Toynbee A.J., Mitrany D., Hogarth D.G., The Balkans. A History of Bulgaria, Serbia, Greece, Rumania, Turkey, Oxford, 1915.

G[rzegorzewski] J., Dragan Cankow, Świat Słowiański, 7 (1911), vol. 1, no. 77.

Grzegorzewski J., Rok przewrotów (Bułgarya 1885/86), Lwów, 1900.

Grzegorzewski J., "Siedmiomiesięczna walka o samoistność Bułgaryi”, Świat Słowiański, 8 (1912), vol. 1 , no. 87 ; vol. 1 , no. 88 ; vol. 1 , no. 89 .

Grzegorzewski J., "Stronnictwa bułgarskie po przewrotach”, Świat Słowiański, 8 (1912), vol. 2, no. 95; vol. 2, no. 96.

Grzegorzewski J., "Stronnictwa bułgarskie za Aleksandra Battenberga", Świat Słowiański, 7 (1911), vol. 2, no. 81.

Huhn A. von, Aus bulgarischer Sturmzeit, Leipzig, 1886.

Jankowski C., Na gruzach Turcji. Zarysy historyczno-publicystyczne, Warszawa, 1915.

Jireček C., Geschichte der Bulgaren, Prag, 1876.

Lipnicki E., "Sprawa bułgarska”, Biblioteka Warszawska, 1 (1886).

Lipnicki E., "Zjazd w Gasteinie i wypadki bułgarskie”, Biblioteka Warszawska, 4 (1886).

Mach R. von, Elf Jahre Balkan. Erinnerungen eines preussischen Offiziers aus den Jahren 18761887, [Breslau], 1889.

Malinowski P., “Militaryzm współczesny”, Ateneum, 22 (1897), no. 2.

Murzyński K., "Serbia i jej przodownictwo”, Niwa, 9 (1880), z. 124.

Piotrowski A., "Z dziejów Carstwa Bułgarskiego. Wspomnienia osobiste”, Tygodnik Illustrowany, 42 (1908). 
Pług A. [A. Pietkiewicz], “Sprawa bułgarska”, Kłosy, 41 (1885), no. 1059.

Wegnerowicz W.R., "Odrodzenie Bułgaryi”, Literatura i Sztuka. Dodatek do Dziennika Poznańskiego, 2 (1913).

Карцов Ю., Семь тет на Ближнем Востоке 1879-1886. Воспоминания политические и личные, Санкт-Петербург, 1906.

Радев С., Строителите на съвременна България, vol. 1-2, София, 1911.

Станев Н., История на нова България 1878-1928, София, 1929.

\section{Secondary literature}

Rubacha J., "Bułgarzy i Bułgaria w ostatniej ćwierci wieku XIX w publikacjach Jana Grzegorzewskiego (kultura, ludność, gospodarka)", Studia z Dziejów Rosji i Europy Południowo-Wschodniej, 51 (2016), no. 1, pp. 23-48.

Rubacha J., Malinowski A., Giza A., Historia Bułgarii 1870-1915. Materiały źródłowe z komentarzami, t. 1: Polityka międzynarodowa, Warszawa, 2006.

Rubacha J., Malinowski A., Historia Bułgarii 1870-1915. Materiały źródłowe z komentarzami, t. 3: Polityka wewnętrzna, Warszawa, 2009.

Wituch T., Tureckie przemiany. Dzieje Turcji 1878-1923, Warszawa, 1980.

Външната политика на България. Документи и материали, ed. Д. Косев, vols. 1-2, София, 1978.

Грънчаров С., "Русофилските политически сили в България (август 1886 - август 1887 г.)", Известия на Института за история, 26 (1983).

Маринов Д., Стебан Стамболов и новейшата ни история, vols. 1-2, София, 1992.

Програми, програмни документи и устави на буржоазните партии в България 1879-1918, ed. В. Николова, Д. Саздов, София, 1992.

Сръбско-българската война 1885. Сборник документи, еd. Е. Харбова, Л. Цветкова, С. Шанов, София, 1985.

Стателова Е., Дипломация на Княжество България 1879-1886, София, 1979.

Стателова Е., Попов Р., Танкова В., История на българската дипломация 1879-1913 г., София, 1994.

Цураков А., Правителствата на България, ч. 1, София, 1996.

Jarosław Rubacha, Professor at the University of Warmia and Mazury in Olsztyn, historian of the Balkans; his research interests focus on: the history of the Balkan Peninsula in the $19^{\text {th }}$ and $20^{\text {th }}$ centuries, the history of Bulgaria and Polish Slavophilia in the early $20^{\text {th }}$ century (j.rubacha@wp.pl). 